\title{
INFLUENCE OF ENDOTHELIN ON HUMAN PLATELET AGGREGATION AND PROSTACYCLIN GENERATION FROM HUMAN VASCULAR ENDOTHELIAL CELLS IN CULTURE
}

\author{
Kazuharu Kato, M.D., Shohei Sawada, M.D., Takeo Toyoda, M.D. \\ Kyoichiro Kobayashi, M.D., Kaoru Shirai, M.D., Katsumi Yamamoto, M.D. \\ Toshiyuki Tamagaki, M.D., Masahito Yamagami, M.D. \\ Mitsuru Yoneda, M.D., Osamu Takada, M.D., Masashi Uno, M.D. \\ Hajime Tsuji, M.D., and Masao Nakagawa, M.D.
}

\begin{abstract}
The effects of endothelin (ET) on the function of cultured human umbilical vein endothelial cells (HUVEC) and that of human platelets were investigated with reference to endothelium-derived relaxing factor (EDRF) and $\mathrm{PGI}_{2}$. Considering the platelets, ET had no effect on platelet-rich plasma (PRP) aggregation, the generation of thromboxane $\mathrm{A}_{2}$ ([TXA $]$ ) from platelets, and cytosolic free calcium ion concentration $\left(\left[\mathrm{Ca}^{++}\right]_{\mathrm{i}}\right.$ ), cAMP content $\left([\mathrm{cAMP}]_{\mathrm{i}}\right)$ or cGMP content $\left([\mathrm{cGMP}]_{\mathrm{i}}\right)$ in platelets. In contrast, the addition of the solution in which HUVEC had been incubated with ET to PRP produced a decrease in PRP aggregation, $\left[\mathrm{TXA}_{2}\right]$, and $\left[\mathrm{Ca}^{+}{ }^{+}\right]_{i}$, and an increase not only in $[\mathrm{cAMP}]_{\mathrm{i}}$ but also in $[\mathrm{cGMP}]_{\mathrm{i}}$ in platelets. In the HUVEC pretreated with acetylsalicylic acid (aspirin), this increase of [cGMP $]_{i}$ was not affected, but the HUVEC-mediated decrease in PRP aggregation, $\left[\mathrm{TXA}_{2}\right]$, and $\left[\mathrm{Ca}^{+}{ }^{+}\right]_{\mathrm{i}}$ induced by ET were not completely abolished. However, the pretreatment of HUVEC with a combination of aspirin and L-NG-monomethyl arginine (LNMMA) as an inhibitor of EDRF completely abolished the HUVEC-mediated decrease in PRP aggregation, $\left[\mathrm{TXA}_{2}\right]$ and $\left[\mathrm{Ca}^{++}\right]_{\mathrm{i}}$ induced by ET, and also abolished the enhancement of $[\mathrm{cGMP}]_{i}$ and $[\mathrm{cAMP}]_{\mathrm{i}}$ in platelets. The $\mathrm{PGI}_{2}$ of $\mathrm{HUVEC}$ was enhanced by ET with no changes in $\left[\mathrm{Ca}^{++}\right]_{i},[\mathrm{cAMP}]_{\mathrm{i}}$ and $[\mathrm{cGMP}]_{\mathrm{i}}$. The ET-induced enhancement was remarkably attenuated by pretreating the HUVEC with aspirin, but not with LNMMA.

We conclude that ET attenuates the aggregation of platelets through a decrease in $\left[\mathrm{TXA}_{2}\right]$ by an increase in $[\mathrm{cAMP}]_{\mathrm{i}}$ via the increase in $\mathrm{PGI}_{2}$ of HUVEC, and by an increase in $[\mathrm{cGMP}]_{i}$ via EDRF.
\end{abstract}

(Jpn Circ J 1992; 56: 422-431)

Key words:

Endothelin

Prostacyclin

EDRF

Platelet aggregation

Human Vascular

Endothelial cells
$\mathbf{T}$ E vaucular endothelial cell produces a vasoactive peptide, endothelin, which exerts a powerful vasoconstrictive effect on smooth muscle cells! While the mechanism

(Received January 24, 1991; accepted October 21, 1991)

Second Department of Medicine, Kyoto Prefectural University of Medicine, Japan

Grant-in-aid for scientific research $(C)$ and Grant-in-aid for encouragement of young scientists from the Ministry of Education, Science and Culture, Japan

Mailing address: Kazuharu Kato, M.D., Second Department of Medicine, Kyoto Prefectural University of Medicine, 465, Kawaramachi-Hirokoji, Kamikyo-ku, Kyoto 602, Japan 
of its action on vascular smooth muscle cells has been investigated with reference to calcium ion kinetics, its physiological action has not been fully investigated. There are several reports on the influence of endothelin on platelet function, but its effect on platelet aggregation, and its mode of action, have not yet been clarified with reference to the interactions among the vascular endothelial cell, platelet and endothelin. We investigated the effects of endothelin-1 on cultured human umbilical vein endothelial cells (HUVEC) and platelet aggregation with respect to its mode of action.

\section{MATERIALS AND METHODS}

\section{1) Preparation of platelet-rich plasma and measurement of platelet aggregation}

Blood was drawn from fasting normal subjects who had not ingested any antiplatelet drugs such as acetylsalicylic acid (aspirin) for at least 2 weeks. Blood was mixed with 0.1 volume of $3.2 \%$ sodium citrate in polypropylene tubes and centrifuged at $250 \mathrm{G}$ for 10 min at room temperature to yield plateletrich plasma (PRP). Platelet-poor plasma was obtained after centrifugation at $1500 \mathrm{G}$ for $15 \mathrm{~min}$. Platelet-rich plasma was diluted with platelet poor-plasma and the platelet counts were adjusted to $300,000 / \mathrm{mm}^{3}$.

Aggregation was measured in a 3-channel platelet aggregometer (Rikadenki Ltd. Osaka, Japan) at $37{ }^{\circ} \mathrm{C}$ with $1 \mathrm{ml}$ cuvettes filled with $500 \mu \mathrm{l}$ platelet suspension stirred at $1000 \mathrm{rpm}$. The baseline of the recording pen was set using the platelet suspension, and $100 \%$ aggregation was set using platelet poor plasma. The extent of aggregation was measured as the maximum increase in light transmission. The percentage of aggregation was calculated by comparison with the curve obtained in the presence of adenosine diphosphate (ADP) (final concentration $\left.2 \times 10^{-6} \mathrm{M}\right)$, which was dissolved in tris buffer solution $(25 \mathrm{mM}$ Tris $\mathrm{HCl}, 130 \mathrm{mM}$ $\mathrm{NaCl}, \mathrm{pH}$ 7.4). Platelet aggregation induced by the addition of ADP was measured in the presence of 1) endothelin alone (final concentration $5 \times 10^{-11}, 5 \times 10^{-9}, 2 \times 10^{-7} \mathrm{M}$ ); and 2) the solution in which the cultured HUVEC were incubated with endothelin in the presence or absence of aspirin, L-NG. monomethyl arginine (LNMMA) or L- arginine. Platelet aggregation in each experiment reached a maximum within $5 \mathrm{~min}$.

\section{2) Culture of vascular endothelial cells}

Vascular endothelial cells were cultured by the method previously described? The primary cultured cells which formed confluent monolayers in $35 \mathrm{~mm}$ in diameter wells were used in the following experiments. There were $2 \times 10^{5}$ HUVEC per well. The cells were identified as vascular endothelial cells by the detection of Weibel-Palade body on electron microscopy, and by the release of angiotensin I-converting enzyme.

a) Preparation of the test solution in which HUVEC were incubated to investigate effect for platelet aggregation induced by $A D P$

After decanting the primary culture medium of HUVEC the cells were incubated at $37^{\circ} \mathrm{C}$ with $500 \mu$ of the conditioned buffer solution (buffer A: $150 \mathrm{mM} \mathrm{NaCl}, 5 \mathrm{mM}$ $\mathrm{KCl}, 1.8 \mathrm{mM} \mathrm{CaCl}, 5 \mathrm{mM}$ glucose, $1 \mathrm{mM}$ $\mathrm{MgCl}_{2}, 10 \mathrm{mM}$ HEPES, $\mathrm{pH}$ 7.4) containing several test reagents for $15 \mathrm{~min}$, and 0.1 volume of an aliquot was added to the test tube to be used in the aggregometer. HUVEC were pretreated with aspirin, LNMMA or L-arginine, by incubation with aspirin $\left(10^{-4} \mathrm{M}\right)$, LNMMA $\left(3 \times 10^{-4} \mathrm{M}\right)$ or L-arginine $\left(10^{-3} \mathrm{M}\right)$ in culture medium for $60 \mathrm{~min}$. After the HUVEC were washed twice with Dulbecco's phosphate buffer solution $(137 \mathrm{mM} \mathrm{NaCl}, 2.7 \mathrm{mM} \mathrm{KCl}, 1 \mathrm{mM}$ $\mathrm{CaCl}_{2}, 1 \mathrm{mM} \mathrm{MgCl}, 1.5 \mathrm{mM} \mathrm{KH} \mathrm{KHO}_{4}, 6.5$ $\mathrm{mM} \mathrm{Na} 2 \mathrm{HPO}_{4}, \mathrm{pH} 7.4$ ), they were further incubated at $37{ }^{\circ} \mathrm{C}$ with $500 \mu$ l of buffer $\mathrm{A}$ containing several test reagents for $15 \mathrm{~min}$, and a volume of 0.1 of an aliquot was added to the test tube to be used in the aggregometer.

\section{3) Assay of cyclic AMP and GMP content in platelets and HUVEC subjected to experi- ments}

The concentration of cyclic AMP and GMP $\left([\mathrm{cAMP}]_{\mathrm{i}}\right.$ and $\left.[\mathrm{cGMP}]_{\mathrm{i}}\right)$ in the platelets or HUVEC was measured by the modified method of Beretz et al5. In brief, $300 \mu$ l of platelet-rich plasma was first incubated with ADP (final concentration $2 \times 10^{-6} \mathrm{M}$ ) or other agents for $5 \mathrm{~min}$. The HUVEC was incubated in buffer A with or without endothelin $\left(5 \times 10^{-9} \mathrm{M}\right)$ for $15 \mathrm{~min}$. After the 
TABLE I

\begin{tabular}{|c|c|c|c|c|c|}
\hline & $\begin{array}{c}\text { Platelet aggregation } \\
(\%)\end{array}$ & $\begin{array}{c}\mathrm{TXB}_{2} \\
\left(\mathrm{ng} / \mathrm{ml} / 3 \times 10^{8}\right. \\
\text { platelets })\end{array}$ & $\begin{array}{c}c A M P \\
\left(\mathrm{pmol} / 3 \times 10^{8}\right. \\
\text { platelets })\end{array}$ & $\begin{array}{c}c G M P \\
\left(\text { pmol/ } 3 \times 10^{8}\right. \\
\text { platelets })\end{array}$ & $\begin{array}{l}{\left[\mathrm{Ca}^{++}\right]_{i}} \\
(\mathrm{nM} M)\end{array}$ \\
\hline $\begin{array}{l}\text { Tris buffer } \\
\quad \text { solution }\end{array}$ & 0 & & & & $118.9 \pm 3.2$ \\
\hline $\begin{array}{l}A D P \\
\quad\left(2 \times 10^{-6} M\right)\end{array}$ & 100 & $478.1 \pm 44.0$ & $45.5 \pm 2.8$ & $40.2 \pm 3.6$ & $214.7 \pm 12.0$ \\
\hline $\begin{array}{l}A D P+E T \\
\quad\left(5 \times 10^{-11} M\right)\end{array}$ & $100.2 \pm 3.2$ & $490.5 \pm 45.6$ & $47.4 \pm 2.5$ & $42.0 \pm 3.9$ & \\
\hline $\begin{array}{l}A D P+E T \\
\quad\left(5 \times 10^{-9} M\right)\end{array}$ & $99.8 \pm 4.1$ & $485.1 \pm 43.1$ & $45.3 \pm 3.0$ & $44.9 \pm 3.5$ & $210.1 \pm 12.7$ \\
\hline $\begin{array}{l}A D P+E T \\
\quad\left(2 \times 10^{-7} M\right)\end{array}$ & $100.5 \pm 3.3$ & $483.4 \pm 43.4$ & $47.3 \pm 3.3$ & $42.6 \pm 3.7$ & $217.4 \pm 13.1$ \\
\hline
\end{tabular}

Direct effect of endothelin-1 (ET; final concentration $5 \times 10^{-11}, 5 \times 10^{-9}, 2 \times 10^{-7} \mathrm{M}$ ) on platelet function (adenosine diphosphate $(A D P)$-induced platelet aggregation, thromboxane $A_{2} \quad\left(T X A_{2}\right)$ concentration, cAMP concentration and cytosolic fee $\mathrm{Ca}++$ concentration $\left.\left([\mathrm{Ca}++]_{i}\right)\right)$.

Data are presented as mean $\pm S E M$.

TABLE II

\begin{tabular}{lc}
\hline & platelet aggregation \\
\hline$A D P$ & 100 \\
\hline Buffer $A$ without $E T$ & 100 \\
\hline$\# E T$ & \\
$\left(5 \times 10^{-13} M\right)$ & $78.9 \pm 4.7^{* * *}$ \\
$\left(5 \times 10^{-11} M\right)$ & $71.3 \pm 3.5^{* *}$ \\
$\left(5 \times 10^{-9} M\right)$ & $57.1 \pm 5.0^{* *}$ \\
$\left(2 \times 10^{-7} M\right)$ & $58.1 \pm 5.2^{* *}$ \\
\hline
\end{tabular}

ADP-induced platelet aggregation by addition of the medium in which human umbilical vein endothelial cells had been incubated with endothelin-1 (ET: $5 \times 10^{-13}, 5 \times 10^{-11}, 5 \times 10^{-9}, 2 \times 10^{-9}$, $\left.2 \times 10^{-7} \mathrm{M}\right)$.

Data are presented as \% aggregation for ADP-induced platelet aggregation and mean $\pm S E M$. ( $n=10,{ }^{*},{ }^{* *}$ represents $p<0.05, p<0.01$ (ADP vs $E T)$ respectively) \#: concentrattion of $E T$ incubated with HUVEC.

reaction was stopped by adding cold trichloroacetic acid (TCA) to achieve a final concentration of $5 \%$, the sample was sonicated using an ultrasonic sonicator in an ice bath and centrifuged (1500G) at $4{ }^{\circ} \mathrm{C}$ for $10 \mathrm{~min}$. The supernatant was obtained and TCA in the supernatant was then extracted twice with 3 volumes of water-saturated ether. The cyclic nucleotides in $100 \mu \mathrm{l}$ of the above-treated supernatant were then assayed using [125I] cyclic AMP and GMP radioimmunoassay (RIA) kits (Yamasa Co. Ltd., Choshi, Japan). The assay values were estimated to be the intracellular content of the cyclic uncleotides.

4) Assay of thromboxane $A_{2}$ concentration in platelets

The concentration of thromboxane $\mathrm{A}_{2}$ in the platelets was measured as the concentration of thromboxane $B_{2}$ by the modified method of Siess et al6 In brief, at the end of the aggregation study, $200 \mu 1$ of platelet-rich plasma which was incubated with ADP (final concentration $2 \times 10^{-6} \mathrm{M}$ ) or other agent for 5 min was acidified to $\mathrm{pH} 3.5$ by $1 \mathrm{~N}-\mathrm{HCl}$ and stirred at $37{ }^{\circ} \mathrm{C}$ before the sample was transferred to acetone at $-20{ }^{\circ} \mathrm{C}$. After centrifugation at $2000 \mathrm{G}$ for $15 \mathrm{~min}$ the supernatant was extracted twice with $1 \mathrm{ml}$ of ethylacetate, then evaporated to dryness in a vacuum. The sample was stored in ethanol at $-20{ }^{\circ} \mathrm{C}$. The concentration of thromboxane $A_{2}$ in $100 \mu$ of the sample was measured as thromboxane $\mathrm{B}_{2}$ using a $\left.{ }^{3} \mathrm{H}\right]$ thromboxane RIA kit (New England Nuclear, Boston, USA).

\section{5) Assay of prostacyclin concentration}

HUVEC were incubated with $500 \mu \mathrm{l}$ of Buffer A containing several test reagents in 
Endothelial cell (-)

$\begin{array}{lr}\text { Buffer A } & 485.1 \pm 43.1\end{array}$

Endothelial cell $(+)$

Buffer A

$343.6 \pm 29.9^{* *}$

Pretreatment with ASA

$487.7 \pm 40.4$

Pretreatment with ET

Pretreatment with $A S A \& E T$

Pretreatment with ASA, LNMMA \& ET

Pretreatment with ASA, LNMMA, L-arginine \& ET

$273.6 \pm 29.3^{* *}$

$436.5 \pm 40.2^{* *}$

$445.0 \pm 34.6^{*}$

$475.7 \pm 32.9$

Effect of the solution in which HUVEC were incubated with or without acetylsalicylic acid $\left(A S A ; 10^{-4} M\right), L$ $N^{G}$-monomethyl arginine (LNMMA; $\left.3 \times 10^{-4} \mathrm{M}\right)$, L-arginine $\left(1 \times 10^{-3} \mathrm{M}\right)$ or endothelin-1 $\left(E T ; 5 \times 10^{-9} \mathrm{M}\right)$ on the generation of platelet thromboxane $A_{2}\left(T X A_{2}\right)$.

Data are presented as mean $\pm S E M .\left(n=10 ;{ }^{*}: p<0.05,{ }^{* *}: p<0.01\right.$ vs buffer $A$ without endothelial cell $)$

TABLE IV

\begin{tabular}{|c|c|c|}
\hline & \multicolumn{2}{|c|}{$\begin{array}{cc}\text { cyclic } & \text { AMP } \\
\left(\text { pmole } / 3 \times 10^{8} \text { platelets }\right)\end{array}$} \\
\hline \multicolumn{3}{|l|}{ Endothelial cell (-) } \\
\hline Buffer $A$ & $45.2 \pm 3.0$ & $40.3 \pm 2.8$ \\
\hline \multicolumn{3}{|l|}{ Endothelial cell $(+)$} \\
\hline Buffer $A$ & $56.2 \pm 4.1^{* *}$ & $42.3 \pm 3.0$ \\
\hline Pretreatment with ASA & $46.4 \pm 2.5$ & $39.1 \pm 2.4$ \\
\hline Pretreatment with ET & $63.3 \pm 4.8^{* *}$ & $57.4 \pm 3.4^{* *}$ \\
\hline Pretreatment with $A S A \& E T$ & $47.2 \pm 1.7$ & $56.0 \pm 3.4^{* *}$ \\
\hline Pretreatment with $A S A, L N M M A \& E T$ & $46.7 \pm 1.7$ & $43.5 \pm 2.6$ \\
\hline Pretreatment with ASA, LNMMA, L-arginine \& ET & $47.0 \pm 1.8$ & $55.8 \pm 2.4^{* *}$ \\
\hline
\end{tabular}

Effect of the solution in which HUVEC were incubated with or without acetylsalicylic acid $\left(A S A ; 10^{-4} M\right), L$ $N^{G}$-monomethyl arginine $\left(L N M M A ; 3 \times 10^{-4} \mathrm{M}\right)$, L-arginine $\left(1 \times 10^{-3} \mathrm{M}\right)$ or endothelin-1 $\left(E T ; 5 \times 10^{-9} \mathrm{M}\right)$ on the platelet cyclic AMP and cyclic GMP generation.

Data are presented as mean $\pm S E M .\left(n=10 ; *{ }^{*}, *\right.$ represents $p<0.05, p<0.01$ vs buffer $A$ without endothelial cell respectively)

$37{ }^{\circ} \mathrm{C}$ for $15 \mathrm{~min}$, and an aliquot was subjected to the assay of prostacyclin concentration. Prostaglandins mainly generated from HUVEC were confirmed to be prostacyclin by thin-layer chromatography from a preliminary experiment with $\left[1-{ }^{14} \mathrm{C}\right]$-arachidonic acid. The prostacyclin released from HUVEC was measured as its stable metabolite, 6-keto prostaglandin $\mathrm{F}_{1 \alpha}$, using $\left[{ }^{3} \mathrm{H}\right]$ 6-keto prostaglandin $\mathrm{F}_{1 \alpha}$ RIA kit (New England Nuclear, Boston, USA).

6) Measurement of cytosolic free calcium ion concentration
The cytosolic free calcium ion concentration was measured by the modified method of Grynkiewicz? In brief, the endothelial cells were scraped from the dishes with a rubber spatula and collected in centrifugation tubes. The cells were then rinsed with $10 \mathrm{ml}$ of buffer A without calcium ions containing $1.0 \%$ bovine serum albumin. After the cells were resuspended in $3 \mathrm{ml}$ of buffer A containing bovine serum albumin they were incubated with $3.2 \mu \mathrm{M}$ fura-2/AM at 37 ${ }^{\circ} \mathrm{C}$ for $45 \mathrm{~min}$ and then diluted to $20 \mathrm{ml}$ with the buffer A containing bovine serum albumin. Following resuspension in $1.0 \%$ bovine 
TABLE V

\begin{tabular}{ll}
\hline \hline & \multicolumn{1}{c}{ platelet aggregation } \\
\hline Endothelial cell (-) & 100 \\
Buffer $A$ & \\
\hline Endothelial cell (+) & $78.9 \pm 4.7^{* *}$ \\
Buffer $A$ & $99.6 \pm 0.3$ \\
Pretreatment with ASA & $57.1 \pm 1.0^{* *}$ \\
Pretreatment with ET & $94.5 \pm 0.9^{* *}$ \\
Pretreatment with ASA \& ET & $99.8 \pm 0.4$ \\
Pretreatment with ASA, LNMMA \& ET & $93.5 \pm 1.1^{* *}$ \\
\hline
\end{tabular}

Effects of the solution in which HUVEC were incubated with or without endothelin- 1 (ET; $\left.5 \times 10^{-9} M\right)$, acetyIsalicylic acid $\left(A S A ; 10^{-3} \mathrm{M}\right)$ on the platelet aggregation.

Data are presented as \% aggregation for $A D P$-induced platelet aggregation and mean $\pm \operatorname{SEM} .(n=10 ; *, * *$ represents $p<0.05, p<0.01$ vs buffer $A$ without endothelial cell respectively)

TABLE VI

$\left[\mathrm{Ca}{ }^{++}\right]_{i}$ of the platelet $(\mathrm{nM})$

Endothelial cell (-)

tris buffer solution

$A D P$

$118.9 \pm 3.2$

$214.7 \pm 12.0^{* * *}$

Endothelial cell (+)

Pretreatment with ET

Pretreatment with ASA \& ET

Pretreatment with ASA, LNMMA \& ET

Pretreatment with ASA, LNMMA, L-arginine \& ET

$155.1+9.5^{* *}$

$181.1 \pm 5.4^{* *}$

$197.8 \pm 17.1^{* *}$

$179.7 \pm 5.6^{* *}$

Effects of the solution in which HUVEC were incubated with or without acetylsalicylic acid $\left(A S A ; 10^{-4} M^{-4}\right.$, $L-N^{G}$-monomethyl arginine $\left(L N M M A ; 3 \times 10^{-4} M\right)$, L-arginine $\left(1 \times 10^{-3} \mathrm{M}\right)$ or endothelin-1 $\left(E T ; 5 \times 10^{-9}\right.$ $M)$ on the platelet cytosolic fee calcium concentration.

Data are presented as mean $\pm S E M .\left(n=10 ; *{ }^{* *}\right.$ represents $p<0.05, p<0.01$ vs tris buffer solution without endothelial cell respectively)

serum albumin solution (cell count 106/ml) they were centrifuged at $250 \mathrm{G}$ for $10 \mathrm{~min}$. Fluorescence signals from the endothelial cell suspensions in the supernatant were recorded in UV-compatible cuvettes utilizing a calcium ion analyzer CAF-100 (Japan Spectro-scopic Co., Ltd., Tokyo, Japan). At first calcium chloride (final concentration 1.8 $\mathrm{mM}$ ) was added to the cell suspension, and then when the fluorescence signals reached a plateau, vasoactive substances such as endothelin (final concentration $5 \times 10^{-9} \mathrm{M}$ ) or thrombin (final concentration $10 \mathrm{U} / \mathrm{ml}$ ) were added to the cell suspension.

The cytosolic free calcium ion concentration of the platelets was also measured by the method described. In brief, platelets were rinsed with $10 \mathrm{ml}$ of buffer $A$ without calcium ions containing $1.0 \%$ bovine serum albumin. After the platelets were resuspended in $3 \mathrm{ml}$ of the above solution, they were incubated with $3.2 \mu \mathrm{M}$ fura-2/AM at 37 ${ }^{\circ} \mathrm{C}$ for $45 \mathrm{~min}$ and then diluted to $20 \mathrm{ml}$ with the above solution. Following resuspension in $1.0 \%$ bovine serum albumin (platelet count $10^{6} / \mathrm{ml}$ ), they were centrifuged at $250 \mathrm{G}$ for $10 \mathrm{~min}$. Fluorescence signals from the platelet suspensions were recorded in UVcompatible cuvettes utilizing a calcium ion analyzer CAF-100. Calibration was done as follows: the maximum fluorescence was obtained by the disruption of HUVEC or the 


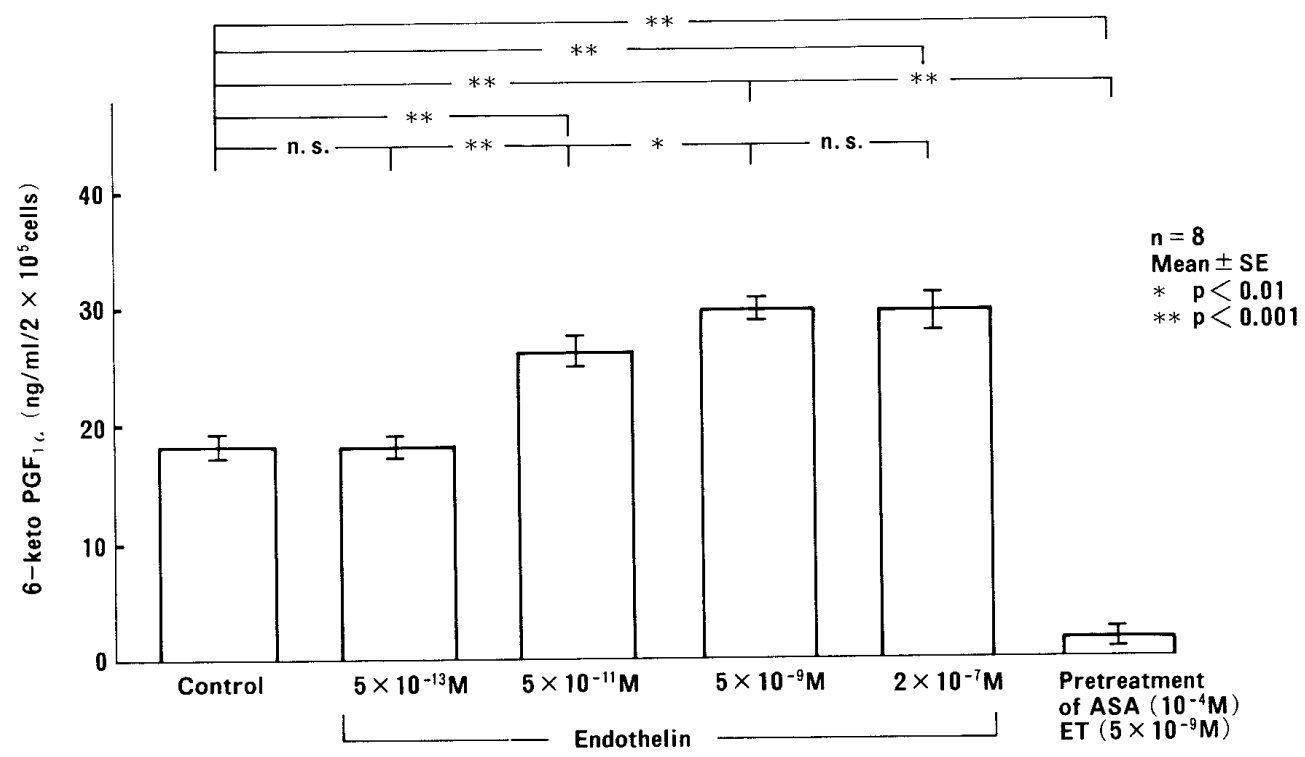

Fig.1. Effect of endothelin-1 (ET; $\left.5 \times 10^{-13}, 5 \times 10^{-11}, 5 \times-9,2 \times{ }^{-7} \mathrm{M}\right)$ on the generation of $\mathrm{PGI}_{2}$ by human umbilical vein endothelial cells; Effect of pretreatment with acetylsalicylic acid (ASA, 10-4 M) on endothelin-1 (ET, $5 \times 10^{-9}$ ) induced $\mathrm{PGI}_{2}$ release from human umbilical vein endothelial cells. Data are presented as mean \pm SEM. $\left(\mathrm{n}=8 ;{ }^{*}, * *\right.$ represents $\mathrm{p}<0.01, \mathrm{p}<0.001$ respectively $)$

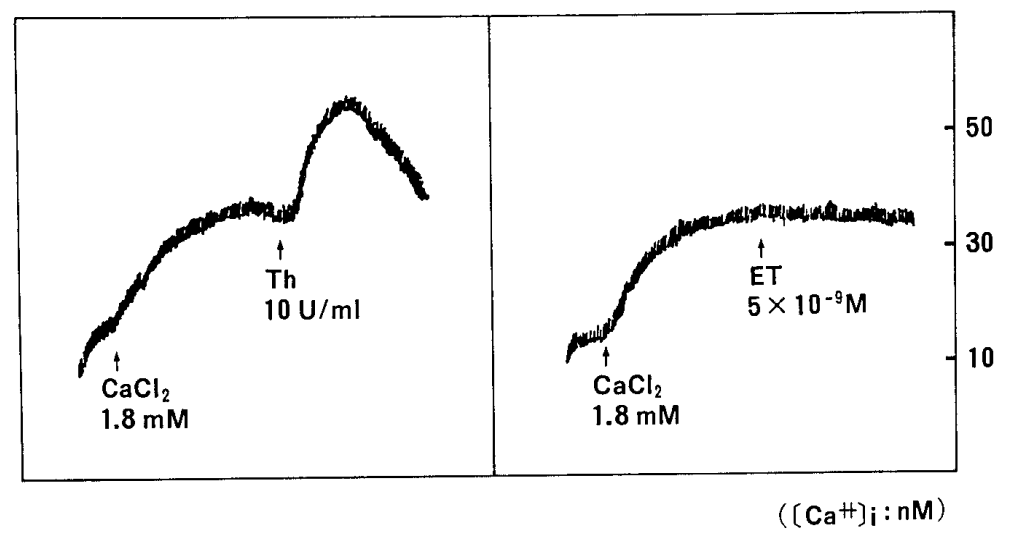

Fig.2. Effect of endothelin-1 $\left(\mathrm{ET} ; 5 \times 10^{-9} \mathrm{M}\right)$ or thrombin $(\mathrm{Th} ; 10 \mathrm{U} / \mathrm{ml})$ on cytosolic free $\mathrm{Ca}^{+}+$concentration of human umbilical vein endothelial cells.

platelets with $0.1 \%$ Triton $\mathrm{X} 100$, and the minimum fluorescence was obtained by the subsequent addition of $1 \mathrm{mM}$ EGTA, $\mathrm{pH}$ 8.0 .

\section{7) Reagents}

The following reagents were used in this experiment: bovine serum albumin (Sigma fraction V, St. Louis, USA), porcine endothelin-1 (Peptide Institute Inc., Osaka, Japan), fura-2 acetomethoxy pentaester (fura-2/AM, Calbiochem, La Jolla, USA), adenosine diphosphate (Sigma Chemical Co., St. Louis, USA), L-N ${ }^{G}$-monomethyl arginine (LNMMA, gift from I. Sakuma
[Hokkaido University, Japan]), L-arginine (Nacalai Tesque, Inc., Kyoto, Japan), acetylsalicylic acid (Nacalai Tesque, Inc., Kyoto, Japan), and human thrombin (Green Cross Corporation, Osaka, Japan).

\section{6) Statistical analysis}

Data (expressed as mean \pm SEM) were compared using analysis of variance. For Fratios significant at the $5 \%$ level or less, Duncan's multiple range test was applied to test for differences between any two groups. Differences at the $5 \%$ level or less $(p<0.05)$ were considered statistically significant. Percentage changes, for which a normal dis- 
TABLE VII

\begin{tabular}{lcc}
\hline \hline & $\begin{array}{c}\text { cyclic AMP } \\
\text { (fmole/ } 2 \times 10^{5} \text { cells) }\end{array}$ \\
\hline Buffer $A$ & $38.2 \pm 2.2$ & $65.4 \pm 4.9$ \\
ET & $37.1 \pm 2.0$ & $66.9 \pm 3.7$ \\
\hline
\end{tabular}

Effect of endothelin-1 (ET; $\left.5 \times 10^{-9} \mathrm{M}\right)$ on the cyclic AMP and cyclic GMP generation of human umbilical vein endothelial cells.

Data are presented as mean $\pm S E M$.

tribution cannot be assumed, were compared using the Kruskal-Wallis non-parametric method for analysis of variance. Whenever the chi-square test results were significant, the Mann-Whitney test was used to determine the significance of the differences between pairs of means.

\section{RESULTS}

\section{1) Effect of endothelin on platelet function}

The addition of endothelin $\left(5 \times 10^{-11}\right.$, $\left.5 \times 10^{-9}, 2 \times 10^{-7} \mathrm{M}\right)$ to PRP had no effect on the ADP-induced platelet rich plasma aggregation, the concentration of thromboxane $\mathrm{A}_{2}, \quad[\mathrm{cAMP}]_{\mathrm{i}}, \quad[\mathrm{cGMP}]_{\mathrm{i}}$ or the $\left[\mathrm{Ca}^{+}\right]_{\mathrm{i}}$ of the platelets (Table I).

\section{2) Function of platelets by adding solution in which HUVEC were incubated with endo- thelin}

The addition of the solution in which HUVEC were incubated with buffer $A$ to platelet-rich plasma caused a decrease of both platelet aggregability and concentration of thromboxane $\mathrm{A}_{2}$ in the platelets. In this experiment, $[\mathrm{cAMP}]_{\mathrm{i}}$ of the platelets increased with no change in $[\mathrm{cGMP}]_{i}$ (Table III-V). These changes in platelet function were prevented by pretreatment with aspirin (Tables III-VI).

The addition of the solution in which HUVEC were incubated with endothelin to platelet-rich plasma caused a decrease in the concentration of thromboxane $\mathrm{A}_{2}$ (Table III), and $\left[\mathrm{Ca}^{+}+\right]_{i}$ in the platelets (Table VI), and an increase in $[\mathrm{cAMP}]_{\mathrm{i}}$ and $[\mathrm{cGMP}]_{\mathrm{i}}$ (Table IV), and a decrease in platelet aggregability, all in a dose-dependent manner. The decrease reached a plateau at $5 \times 10^{-9}$ $M$ of endothelin (Table II). The endothelin induced decrease in platelet function recovered partially in the presence of aspirin (Table III-VI). Namely, when HUVEC were pretreated with aspirin, the addition of the solution in which HUVEC were incubated with endothelin $\left(5 \times 10^{-9} \mathrm{M}\right)$ to platelet rich plasma decreased the endothelin-induced increase of $[\mathrm{cAMP}]_{\mathrm{i}}$, but had no effect of the endothelin-induced increase of $[\mathrm{cGMP}]_{i}$; the endothelin-induced decrease of platelet aggregability, the concentration of thromboxane $\mathrm{A}_{2}$, and $\left[\mathrm{Ca}^{++}\right]_{i}$ in the platelets was not completely abolished (Tables III-VI). Furthermore the combined pretreatment of HUVEC with aspirin and $\mathrm{L}-\mathrm{NG}^{\mathrm{G}}$-monomethyl arginine (LNMMA) $\left(3 \times 10^{-4} \mathrm{M}\right)$ completely abolished the HUVEC-mediated decrease of platelet-rich plasma aggregation by endothelin, thromboxane $\mathrm{A}_{2}$ generation and $\left[\mathrm{Ca}^{++}\right]_{\mathrm{i}}$. It also abolished the enhancement of $[\mathrm{cGMP}]_{\mathrm{i}}$ as well as that of $[\mathrm{cAMP}]_{\mathrm{i}}$ in the platelets, while the inhibitory effect of LNMMA was abolished by pretreatment with L-arginine $\left(1 \times 10^{-3} \mathrm{M}\right)$ (Table III - VI).

\section{3) Effects of endothelin on the generation of $\mathrm{PGI}_{2}$ by $\mathrm{HUVEC}$}

The generation of $\mathrm{PGI}_{2}$ from HUVEC was enhanced by endothelin $\left(5 \times 10^{-11}, 5 \times-9\right.$, $\left.2 \times 10^{-7} \mathrm{M}\right)$ in a dose-dependent manner. This enhancement reached a plateau at $5 \times 10^{-9} \mathrm{M}$ (Fig. 1). However, the addition of endothelin $\left(5 \times 10^{-9} \mathrm{M}\right)$ to the cell suspension of HUVEC had no effect on $\left[\mathrm{Ca}^{++}\right]_{\mathrm{i}}$ (Fig. 2), [cAMP $]_{\mathrm{i}}$ and $[\mathrm{cGMP}]_{\mathrm{i}}$ (Table VII). When the HUVEC were pretreated with aspirin, the basal and endothelin-induced enhancement of $\mathrm{PGI}_{2}$ generation decreased remarkably (Fig. 1).

\section{DISCUSSION}

Vascular endothelial cells have recently been shown to display an antithrombotic action via the generation of $\mathrm{PGI}_{2}{ }^{8}$, tissue plasminogen activator, or thrombomodulin 10 and to regulated the contraction and relaxation of smooth muscle cells via the generation and release of such vasoactive substances as endothelium-derived relaxing factor (EDRF) ${ }^{11}{ }^{1} \mathrm{PGI}_{2}$ and endothelin. There are numerous reports concerning the mechanism of their generation, release and mode of 
action. Endothelin, a novel 21-amino acid peptide purified from the culture medium of porcine aortic endothelial cells, has been recognized to be a highly potent vasoconstrictor; its physiological role has been investigated!

The effect of endothelin on vascular smooth muscle cells include the activation of voltage-dependent $\mathrm{Ca}^{+}+$channel in smooth muscle cells ${ }^{12}$ an activation of phospholipase $\mathrm{C}^{13}$ and phospholipase $\mathrm{A}_{2},{ }^{14}$ and calcium ion mobilization from the storage site via an enhancement of $\mathrm{IP}_{3}$ generation 15 Since few reports have investigated the influence of endothelin on the platelet and the vascular endothelial cell, we studied the effects of endothelin on HUVEC and human platelet aggregation in vitro.

In this study the addition of endothelin alone to human platelets had no effect on ADP-induced platelet aggregation. This finding was supported by the observation in which the direct addition of endothelin to platelet rich plasma had no effect on the concentration of thromboxane $\mathrm{A}_{2},[\mathrm{cAMP}]_{\mathrm{i}}$ or $\left[\mathrm{Ca}^{++}\right]_{\mathrm{i}}$ of the platelet.

On the other hand, from the observation that the addition of the solution in which HUVEC were incubated with buffer A decreased ADP-induced platelet aggregation, but that its inhibition was remarkably attenuated when HUVEC were pretreated with aspirin, we inferred that the inhibition of platelet aggregation was caused by prostanoids such as the $\mathrm{PGI}_{2}$ derived from vascular endothelial cells.

Thiemermann et al! 6 reported that endothelin inhibited the ADP-induced platelet aggregation in the anesthetized rabbit, and that indomethacin abolished the endothelininduced inhibition of platelet aggregation. Those investigators concluded that endothelin inhibited the function of platelets in vivo due to the release of $\mathrm{PGI}_{2}$ or $\mathrm{PGD}_{2}$. While that conclusion was obtained from a study of the inhibitory effects of indomethacin without the direct measurement of prostaglandins, our experimental results support those findings.

It is well known that vascular endothelial cells produce $\mathrm{PGI}_{2}$ and inhibit platelet aggregation. The mechanism of this action is considered due to an increase in cAMP in the platelets induced by $\mathrm{PGI}_{2}$, accompanied by a decrease in thromboxane $\mathrm{A}_{2}$ generation $1^{7,18}$ We previously reported the inhibitory mechanism of platelet aggregation by human vascular endothelial cells? Pretreatment of vascular endothelial cells with endothelin indicated the above-mentioned mechanisms. The endothelin-induced inhibition of platelet aggregation is thought to be developed by the increased cAMP concentration in the platelet via the enhancement of prostanoids such as $\mathrm{PGI}_{2}$ released from the endothelial cells by endothelin. Since in the pretreatment study of HUVEC with aspirin the addition of the solution in which HUVEC were incubated with endothelin to PRP decreased the endothelin-induced increase of $[\mathrm{cAMP}]_{i}$, but had no effect on the endothelin-induced increase of $[\mathrm{cGMP}]_{i}$, and since the endothelin-induced decrease of platelets aggregability and the concentration of thromboxane $\mathrm{A}_{2}$ and $[\mathrm{Ca}++]_{i}$ in the platelets were not completely abolished, it seemed that an enhancement by such other substances as EDRF was involved in the inhibitory effect on platelet aggregation. We therefore investigated the implied effect of EDRF on this mechanism, utilizing LNMMA as an inhibitor of EDRF!9 The combined pretreatment of HUVEC with aspirin and LNMMA completely abolished the HUVEC-mediated, endothelin-induced decrease of platelet-rich plasma aggregation, while the inhibitory effect of LNMMA disappeared with pretreatment of L-arginine. It was thus suggested that endothelin inhibited the aggregation of platelets not only via $\mathrm{PGI}_{2}$ generation, but also via the stimulation of EDRF release.

Simultaneously, it was shown by radio immunoassay that endothelin increased $\mathrm{PGI}_{2}$ generation in human vascular endothelial cells. There are previous reports concerning the $\mathrm{PGI}_{2}$ enhancement with endothelin. For instance, de Nucci et al ${ }^{20}$ reported that endothelin released $\mathrm{PGI}_{2}$ and thromboxane $\mathrm{A}_{2}$ in pig or rat isolated lungs. Rae et $\mathrm{al}^{21} \mathrm{re-}$ ported that endothelin enhanced $\mathrm{PGI}_{2}$ and $\mathrm{PGE}_{2}$ generation, using bioassay or RIA methods in the isolated kidney and spleen of the rabbit. Our results support those reports. Our study revealed that a lower concentration of endothelin (less than $5 \times 10^{-9}$ M) enhanced $\mathrm{PGI}_{2}$ generation. The amount reached a plateau at concentrations exceed- 
ing $5 \times 10^{-9} \mathrm{M}$ endothelin, and endothelin enhanced $\mathrm{PGI}_{2}$ generation of human vascular endothelial cells without a change in the $\left[\mathrm{Ca}^{++}\right]_{\mathrm{i}}$.

In a previous study of HUVEC we reported the mechanism of $\mathrm{PGI}_{2}$ generation and release with reference to $\mathrm{Ca}^{++}, \mathrm{Na}^{+}$ kinetics and cyclic nucleotides?2 those experimental results indicate that $[\mathrm{Ca}++]_{i}$ does not contribute to the endothelin-induced $\mathrm{PGI}_{2}$ enhancement of vascular endothelial cells. This enhancement may be due to such mechanisms as; 1) an influence on the kinetics of cyclic nucleotides; 2) an influence on $\mathrm{Na}^{+}$kinetics such as $\mathrm{Na}^{+}-\mathrm{K}^{+}$ATPase or $\mathrm{Na}^{+}-\mathrm{Ca}^{++}$exchange system; or 3 ) a mechanical stimulation of the endothelial cell membrane.

In conclusion, endothelin synthesized in the vascular endothelial cells is thought to 1) enhance $\mathrm{PGI}_{2}$ generation in endothelial cells, despite a lack of any direct influence on platelet aggregation; and 2) to inhibit platelet aggregation through an increased cAMP in the platelet, and even more so, through a decrease in thromboxane $\mathrm{A}_{2}$ generation. Simultaneously, endothelin is thought to enhance the release of EDRF from endothelial cells, and to inhibit platelet aggregation through an increase in cGMP in the platelet and more so through the decrease in thromboxane $A_{2}$ generation.

It is unclear whether the endothelininduced $\mathrm{PGI}_{2}$ generation and EDRF release may act as a feedback mechanism for endothelin-induced vasoconstriction, because the vasoconstrictive activity of endothelin lasts for a longer period while the activity of $\mathrm{PGI}_{2}$ or EDRF lasts for a short period. Further investigation is required to clarify the complex interactions discussed.

\section{Acknowledgments}

This work was partly supported by grant-in-aid for scientific research (C) No. 02807090 and grant-in-aid for the encouragement of young scientists No. 03770500 from the Ministry of Education, Science and Culture of Japan.

\section{REFERENCES}

1. YANAGISAWA M, KURIHARA H, KIMURA $S$ et al: A novel potent vasoconstrictor peptide produced by vascular endothelial cells. Nature 1988; 332: $411-415$
2. HERMAN F, MAGYAR $\mathrm{K}$, CHABRIER $\mathrm{P}$, BRAQUET P, FILEP J: Prostacyclin mediates antiaggregatory and hypotensive actions of endothelin in anesthetized beagle dogs. BrJ Pharmacol 1989; 98: 38-40

3. TOYODA T, SAWADA S, NIWA I et al: Effect of $\mathrm{Ca}$ antagonists on $\mathrm{PGI}_{2}$ generation in cultured human vascular endothelial cells; relationship between intra- and extracellular $\mathrm{Ca}^{++}$and cyclic nucleotides. Blood \& Vessel 1985; 16: 247-257

4. WEIBEL ER, PALADE E: New cytoplasmic components in arterial endothelia. Cell Biol 1964; 23: $101-112$

5. BERETZ A, STERLE A, ANTON R, CAZENAVE JP: Role of cyclic AMP in the inhibition of human platelet aggregation by quercetin, a flavonoid that potentiates the effect of prostacyclin. Biochem Pharmacol 1981; 31: 3597-3600

6. SIESS W, ROTH P, WEBER PC: Stimulated platelet aggregation, thromboxane $\mathrm{B} 2$ formation and platelet sensitivity to prostacyclin. A critical evaluation. Thromb Haemost 1981; 45: 204-207

7. GRYNKIEWICZ G, POENIE M, TSIEN RY: A new generation of $\mathrm{Ca}^{+}+$indicator with greatly improved fluorescence properties. J Biol Chem 1985; 260: $3440-3450$

8. MONCADA S, GRYGLEWSKI R, BUNTING S, VANE JR: An enzyme isolated from arteries transforming prostaglandin endoperoxides to an unstable substance that inhibit platelet aggregation. Nature 1976; 263: 663-665

9. LEVIN EG, MARZEC U, UNDERSON J, HARKER LA: Thrombin stimulates tissue plasminogen activator release from cultured human endothelial cells. J Clin Invest 1984; 74: 1988-1995

10. MARUYAMA I, SALEM HH, MAJERUS PH: Coagulation factor $\mathrm{Va}$ binds to human umbilical vein endothelial cells and accelerates protein $\mathrm{C}$ activation. J Clin Invest 1984; 74: 224-230

11. FURCHGOTT RF: Role of endothelium in responses of vascular smooth muscle. Circ Res 1983; 53: $557-573$

12. VAN RENTERGHEM C, VIGNE P, BARHANIN J, SCHMID-ALLIANA A, FRELIN C, LAZDUSKI M: Molecular mechanism of action of the vasoconstrictor peptide endothelin. Biochem Biophys Res Commun 1988; 157: 977-985

13. RESINK TJ, SCCOT-BURDEN T, BUHLER FR: Endothelin stimulates phospholipase $C$ in cultured vascular smooth muscle cells. Biochem Biophys Res Commun 1988; 157: 1360-1368

14. RESINK TJ, SCCOT-BURDEN T, BUHLER FR: Activation of phospholipase A2 by endothelin in cultured vascular smooth muscle cells. Biochem Biophys Res Commun 1989; 158: 279-286

15. MARSDEN PA, DANTHULURI NR, BRENNER BM, BALLERMANN BJ, BROCK TA: Endothelin action on vascular smooth muscle involves inositol trisphosphate and calcium mobilization. Biochem Biophys Res Commun 1989; 158: $86-93$

16. THIEMERMANN C, LINDBURY PS, THOMAS GR, VANE JR: Endothelin-1 releases prostacyclin and inhibits ex vivo platelet aggregation in the anesthetized rabbit. J Cardiovasc Pharmacol 1989; 
13: $138-141$

17. TATESON JE, MONCADA S, VANE JR: Effect of prostacyclin (PGX) on cyclic AMP concentration in human platelets. Prostaglandins, 1977; 13: 389-397

18. GORMAN RR, WIERENGA W, MILLER OV: Independence of the cyclic AMP-lowering activity of thromboxane A2 from the platelet release reaction. Biochim Biophys Acta 1979; 572: 95-104

19. SAKUMA I, STUEHR DJ, GROSS SS, NATHAN C, LEVI R: Identification of arginine as precursor of endothelium-derived relaxing factor. Proc Natl Acad Sci USA 1988; 85: 8664-8667

20. DE NUCCI G, THOMAS R, D' ORLENS-JUSTE
P, ANTUNES E, WALDER TD, VANE JR: Pressor effects of circulating endothelin are limited by its removal in the pulmonary circulation and by the release of prostacyclin and endothelium-derived relaxing factor. Proc Natl Acad Sci USA 1988; 85: 9797-9800

21. RAE GA, TRYBULES M, DE NUCCI G, VANE JR: Endothelin-1 releases eicosanoids from rabbit isolated perfused kidney and spleen. $J$ Cardiovasc Pharmacol 1989; 13: 89-92

22. TOYODA T, SAWADA S, SHIRAI K et al: The regulatory mechanisms of prostacyclin generation in human vascular endothelial cells. Jpn J Clin Pathol 1989; 16: 127-133 